\title{
Cezary Zalewski \\ Panny z prowincji. \\ Ze wspomnień cyklisty Bolesława Prusa wobec mitów miłości
}

\begin{abstract}
Zalewski Cezary, Panny z prowincji. "Ze wspomnień cyklisty" Bolesława Prusa wobec mitów miłości [Provincial young ladies. Bolesław Prus's Ze wspomnień cyklisty [Memoirs of a cyclist] and love myths]. „Przestrzenie Teorii" 11. Poznań 2009, Adam Mickiewicz University Press, pp. 165-181. ISBN 978-83-232-1986-6. ISSN 1644-6763.
\end{abstract}

The article places the now forgotten short story by Bolesław Prus Ze wspomnien cyklisty in the mythological and metaliterary context. The prevalent role of amorous plots in this work thus becomes explained through a reference to the myth of Androgyne, solidified in Plato's Feast, that permeated Polish literature following the Romantic (A. Mickiewicz's Forefathers, Part IV) and modernist works ( $\mathrm{S}$. Przybyszewski's Androgyne). The article shows Prus's critical attitude to thus outlined tradition, which assumes a direct and spontaneous nature of amorous desire, since the story's protagonist only "falls in love" when other suitors appear with whom he can compete for women's favours. At the same time, the deconstruction of the androgynous myth reveals yet another concept of desire. Hence the text meets the requirements of the "constructive parody" described by M. Głowiński.

W Notatkach do powieści „Cykliści” Prus w akapicie poświęconym bohaterowi zapisał uwagę, która podsumowuje jego perypetie: „Nie można bawić się chłopami, ani pannami"1. Pisarz zatem nie rozdziela problematyki związanej ze wsią od tej, która dotyczy relacji erotycznych. Ta sugestia znajduje zresztą potwierdzenie w samym utworze, który łączy oba aspekty w sposób harmonijny, aczkolwiek zagadkowy. Związek między nimi do tego stopnia nie jest oczywisty, iż dotychczasowe interpretacje oparte są na selektywnym wyborze, który faworyzuje jeden $\mathrm{z}$ nich kosztem drugiego. Konsensus panuje jedynie w kwestii krytycznego stanowiska Prusa (owego: nie można), później natomiast zaczynają się różnice, zgodnie z którymi $Z e$ wspomnień cyklisty albo podważa modernistyczny erotyzm ${ }^{2}$, albo - romantyczne nastawienie do kwestii społecznych ${ }^{3}$.

${ }^{1}$ B. Prus, Notatki do powieści „Cykliści”, „Archiwum Literackie”, t. XIX, red. E. Pieścikowski, Wrocław 1974.

2 Por. J. Tynecki, Eros rozczqsthowany (albo: Prus wobec Androgyne), w: Światopoglqud pozytywizmu, Łódź 1996; M. Glowiński, Prus - parodysta: „Ze wspomnień cyklisty”, w: Monolog wewnętrzny Telimeny i inne szkice, Kraków 2007.

3 T. Budrewicz, Farys spieszony. Wokót „Ze wspomnieñ cyklisty”, w: Jubileuszowe "Żniwo u Prusa”, pod red. Z. Przybyły, Częstochowa 1998. 
Sądzę jednak, iż rozdzielanie obu tych aspektów jest zabiegiem sztucznym, dlatego każda interpretacja tego opowiadania stoi przed problemem ich połączenia. Zadanie to jest wykonalne dzięki sugestii Prusa, który nadał - nie tylko zresztą temu - utworowi kompozycję ramową, rozpoczynając go i kończąc na kwestii miłosnej. Jeśli jednak erotyzm odgrywa dominującą (i syntetyzującą) rolę, to musi zostać ujęty w kategoriach bardziej uniwersalnych. Rację ma więc Jerzy Tynecki, który wiąże koncepcję Prusa z Platońską Ucztą, a ściślej: z opowiadaniem jednego $z$ uczestników dysputy, które zawiera słynną wizję androgynizmu. Dodać wszakże należy, iż pisarz zapewne korzystał z wersji zapośredniczonej, która funkcjonowała w literaturze romantycznej (Adam Mickiewicz) oraz modernistycznej (Stanisław Przybyszewski).

Celem niniejszego artykułu jest zbadanie relacji między tymi trzema poziomami: platońskim „architekstem”, jego dwoma polskimi odmianami oraz propozycją Prusa. W ten sposób, jak sądzę, można będzie wyjaśnić, na czym w Ze wspomnień cyklisty polega koegzystencja wątku miłosnego z podróżą przez podwarszawską wieś.

Pomimo iż w Uczcie Arystofanes przedstawia narrację, w której pojawia się skomplikowana fabuła, to jednak najważniejsza pozostaje jej konkluzja. Komediopisarz stwierdza zatem, iż działania kochanków dążą do:

stopienia się w jedno w uściskach i ciał zespoleniu. A stąd to wszystko pochodzi, że dawna natura nasza była właśnie taka, że były z nas skończone całości. Miłość jest na imię temu popędowi i dążeniu do uzupełnienia siebie, do całości. Jak mówię, przedtem były z nas jedności (192 E) ${ }^{4}$.

Miłość zatem powstaje $\mathrm{z}$ niedoskonałości i braku. Jest doświadczeniem, w którym podmiot stwierdza swe ograniczenie i stara się je przezwyciężyć, znajdując najbliższą, tj. najbardziej podobną do siebie, osobę. Dzięki temu miłość staje się pełnym zespoleniem, które niweluje w każdym wymiarze odrębność obojga kochanków.

$\mathrm{Z}$ taką koncepcją Erosa nie zgadza się już Sokrates, a raczej Diotyma, która w swoim wywodzie nawiązuje do wypowiedzi Arystofanesa, stwierdzając, iż:

miłość ani połowy nie szuka, ani całości, jeśli nie będzie właśnie jakieś dobro.

[...] Przecież czlowiek rad by sobie i ręce, i nogi poobcinal, gdyby mu się zepsute wydawały i złe. Więc uważam, że człowiek niekoniecznie to kocha, co ,jego własne", chyba że to ,jego" jest właśnie dobre, a inne złe (205 E).

${ }^{4}$ W ten sposób odsyłam do: Platon, Uczta, przeł. W. Witwicki, Warszawa 1982. 
Diotyma podtrzymuje relacyjną naturę miłości, niemniej jednak domaga się, aby jej „cel” spełniał kwalifikacje, związane z partycypacją w odpowiedniej idei. K. Dover trafnie wydobył przesłanki, które zakłada ten argument:

Diotyma bezpośrednio atakuje założenie, bez którego wyjaśnienie Erosa przez Arystofanesa nie może zostać utrzymane: to mianowicie, że każda osoba szuka, kocha i pielęgnuje siebie i to, co jest lub było częścią samego siebie ${ }^{5}$.

Androgynizm, po pierwsze, prowadzi do miłości własnej, w której druga osoba jest traktowana jak rozszerzenie czy podwojenie samego ,ja”. Z tego właśnie powodu, po drugie, odszukiwanie utraconej połowy wyklucza jej autentyczne rozpoznanie ${ }^{6}$. Dover określa androgyniczne pragnienie mianem upodobania (preference) i opisuje jego funkcjonowanie w następujący sposób:

Kiedy pragnienie A w stosunku do B staje się „upodobaniem”, często zdarza się, iż $\mathrm{B}$ nie zwraca na siebie uwagę obiektywnie upragnionymi jakościami, tak że $\mathrm{C}$ nie rozumie, dlaczego A preferuje $\mathrm{B}$, a owo upodobanie A pozostaje niewzruszone nawet wobec dostępności nieskończenie upragnionego $\mathrm{D}^{7}$.

Dover dodaje, iż ów trzeci podmiot $\mathrm{C}$ nigdy nie zainteresuje się osobą $\mathrm{B}$, ponieważ została ona wybrana przez A w sposób skrajnie idiosynkratyczny, czyli z pominięciem tego, co w danej społeczności jest uznawane za cenne.

Eros w ujęciu Arystofanesa zakłada zatem samozwrotną naturę pragnienia. Podmiot jest bowiem zarówno celem miłości, jak i jej wyłącznym źródłem: to on decyduje, kto okaże się „drugą" połową, ponieważ wybór ten ostatecznie jemu samemu służy. Z takim właśnie ujęciem polemizuje Sokrates wymagający od miłości zarówno bezinteresownego charakteru, jak i doskonałości, która powstaje dzięki połączeniu wartościowych kochanków8.

5 K.J. Dover, Aristophanes' speech in Plato's Symposium, „The Journal of Hellenic Studies” 1966, vol. 86, s. 48.

${ }^{6} \mathrm{Na}$ tę konsekwencję zwraca uwagę wielu komentatorów Uczty. R.A. Markus pisze, iż dla Arystofanesa: "Miłość jest tożsama z tym pragnieniem dopełnienia; jej obiekt, który może być skądinąd nieznany, jest określony wylączne jako będący "uzupełnieniem» [...] potrzeby kochanka” - R.A. Markus, The Dialectic of Eros in Plato's Symposium, "Downside Review” 1955, vol. 73, s. 222; por. S. Bernardete, On Plato's Symposium, München 1994, s. 55-59.

7 K.J. Dover, op. cit., s. 49.

${ }^{8}$ M. Eliade dowodzi, iż idea doskonałości, jaka powstaje przez połączenie przeciwieństw, jest pierwotną, religijną interpretacją mitu Androgyne - por. M. Eliade, Mefistofeles $i$ Androgyn, przeł. B. Kupis, Warszawa 1999, s. 122-133. 
Niejednokrotnie już zauważano, iż Dziady Adama Mickiewicza dokonują restytucji mitu androgynicznego ${ }^{9}$, chociaż stopień jego alegacji wciąż pozostaje kwestią otwartą. Analogie między romantyczną miłością a koncepcją Arystofanesa istotnie są liczne. Najważniejsze z nich mają wyraźnie antysokratejski charakter, gdyż są odpowiedzią na krytyczne uwagi filozofa. I Dziewica (z I części), i Gustaw (z IV części) twierdzą, iż unia kochanków jest harmonijna, prowadząca do wewnętrznej doskonałości, dlatego wyklucza egoizm. Ich związek nie jest również oparty na braku rozpoznania; wręcz przeciwnie: pojawienie się kobiety ma naturę epifanii, w której objawia się osoba o nadnaturalnych cechach. Scenariusz Arystofanesa zostaje jeszcze potwierdzony w dwóch kolejnych aspektach. Więź między kochankami uzyskuje bowiem boską sankcję, a nawet przyjęta zostaje teoria miłosnej predestynacji ${ }^{10}$, zgodnie $\mathrm{z}$ którą związek ich dusz jest przedustawnym dziełem samego Boga. Wynika z tego, po drugie, iż faktyczne połączenie kochanków jest tyleż pewne, ile nieprzewidywalne, niezależne od ich działań $\mathrm{i}-\mathrm{z}$ ich perspektywy - dokonuje się przypadkowo.

Nieplanowane spotkanie prowadzi do Gustawa i jego kochankę do autentycznej komunii. Na tym właśnie polega odstępstwo Mickiewicza, które określone zostało mianem „androgynizmu spełnionego”, ponieważ:

Gustaw odnalazł swoją utraconą połowę istnienia. Największe pragnienie miłosne, aby zamienić się w lubą osobę, by z dwu stać się jednym, zrealizowało się tu na ziemi zamienionej dzięki potędze uczucia w rajski ogród ${ }^{11}$.

Arystofanes sądził, iż w tej sytuacji kochanków nic, poza śmiercią, nie jest już w stanie rozdzielić, ponieważ sprzyjają im nawet istoty nadprzyrodzone. Los romantycznego bohatera okazuje się jednak odmienny, ale brak jest podstaw, aby sądzić, iż spotkała go kara ze strony zawistnych bogów ${ }^{12}$.

Kiedy Gustaw snuje fantastyczny projekt pojawienia się na uczcie weselnej swojej kochanki, stwierdza, iż nawet wówczas nie zostałby dopuszczony do niej, ponieważ:

${ }^{9}$ Por. M. Janion, M. Żmigrodzka, IV część „Dziadów" $i$ wczesnoromantyczny bohater egzystencji, „Pamiętnik Literacki” 1987, z. 1, s. 7-10; M. Rudaś-Grodzka , „Sprawić, aby idee śpiewały". Motywy platońskie w życiu i twórczości Adama Mickiewicza w okresie wileńsko-kowieńskim, Warszawa 2003, s. 238-255; B. Dopart, Mickiewiczowski romantyzm przedlistopadowy, Kraków 1992, s. 99-100.

${ }^{10}$ M. Janion, M. Żmigrodzka, op. cit., s. 7.

${ }^{11}$ M. Rudaś-Grodzka, op. cit., s. 245.

12 Por. tamże, s. 251, 255. 
Ty pod zazdrośnych oczu, chytrych żądeł strażą!

Ani obaczyć nie wolno bezkarnie.

Pożegnać, porzucić każą... (IV, 1075-1077)13

W tej hipotetycznej scenie zawarta jest sugestia, iż spełniona miłość stała się obiektem zazdrości innych. Ich - a zwłaszcza tego, który jest panem młodym - uczucie jest zatem wtórne, zapośredniczone; jest zwykłą kopią tego, które narodziło się spontanicznie w sercu Gustawa.

Inni (owi „źli ludzie”) okazali się silniejsi, i to nie tylko dlatego, że odebrali mu ukochaną, ale również $\mathrm{z}$ powodu upokorzenia, do jakiego doprowadzili. Bohater bowiem zbyt wnikliwie analizuje siebie, aby nie odkryć (por. IV, 1050), iż nowy związek jego ukochanej w nim samym sprowokował zazdrość i wynikające z niej rozdarcie. Gustaw doświadcza zatem sprzecznych uczuć: jeszcze bardziej uwielbia kochankę, ale równocześnie jej nienawidzi. Zamiast androgynicznego spełnienia pojawia się dialektyka przyciągania i odpychania, która znajduje swój final w samobójczej decyzji.

\section{III}

Androgyne Stanisława Przybyszewskiego wykorzystuje wątki z Uczty Platona oraz Dziadów Mickiewicza. Synkretyzm jest zauważalny przede wszystkim w dwudzielnej kompozycji, która w pierwszej części ( $W$ godzinie cudu) umieszcza androgynizm spełniony oraz rozstanie, natomiast w drugiej (Androgyne) - perspektywę ponownego zjednoczenia kochanków, jakie dokona się w zaświatach po przejściu przez bramę śmierci.

Przybyszewski przejmuje także koncepcję przypadkowego spotkania, która tym razem zostaje rozszerzona. Bohater bowiem nie tyle czeka na wizytę, ile aktywnie stara się odnaleźć swoją drugą połowę, która dała mu zaledwie znak. Jednakże wszystkie jego wysiłki (na jawie i we śnie) okazują się bezcelowe, ponieważ kochanka sama decyduje o czasie i miejscu swego objawienia.

Nie bez znaczenia pozostają także różnice. Żeby uzasadnić rozstanie, Przybyszewski nie wprowadza „złych ludzi”, pozostawiając decyzję odejścia samej kochance. Jej wyjaśnienie jest niezwykle znamienne:

Odeszłam od Ciebie, boś patrząc na mnie, patrzał w Twoją własną duszę - bo jestem ciałem Twej myśli, jestem kształtem i ciałem Twych tęsknot, wyrazem Twych uczuć i ruchem Twej woli... $(\mathrm{A}, 448)^{14}$.

13 W ten sposób odsylam do: A. Mickiewicz, Dziady. Poema, Warszawa 1991; cyfry w nawiasie oznaczają kolejno część i numery wersów.

${ }^{14} \mathrm{~W}$ ten sposób odsylam do: S. Przybys zews ki, Androgyne, w: Poematy prozq, wybór, wstęp i opracowanie G. Matuszek. Kraków 2003; cyfra w nawiasie oznacza stronę. 
Gabriela Matuszek słusznie zatem zauważa, iż:

Bohater Androgyne ujrzawszy ukochaną „ujrzał samego siebie”. Mit Androgyne można by zatem traktować również jako swego rodzaju wariację mitu Narcyza, oglądającego własne odbicie w lustrze wody ${ }^{15}$.

Kochanka chociaż kusi swoją cielesnością, jest jednak alter ego bohatera. Przybyszewski nie rozstrzyga, na ile tego typu narcyzm ma egoistyczne podłoże; postać kocha bowiem zarówno siebie, jak i swoją wybrankę w taki sposób, iż uczucia tego nie sposób rozdzielić.

\section{IV}

Klamrowa kompozycja Ze wspomnień cyklisty grupuje wątki miłosne w początkowej oraz końcowej partii tekstu. Symetryczny charakter budowy zostaje podkreślony za pomocą analogicznych powtórzeń, które dotyczą postaci kobiecych. Początek fabuły zawiera bowiem perypetie Anastazego z dwiema bohaterkami: Henryką i Karoliną; natomiast final narracji przynosi podobne wydarzenia, w których bierze udział Zosia oraz Hania. Takie podwojenie nie ma jednakże natury tautologicznej, ponieważ partia początkowa nawiązuje do Dziadów Mickiewicza, a końcowa - do Androgyne Przybyszewskiego.

Wszelako w obu przypadkach Prus powraca do Arystofanesa, gdyż nie przedstawia żadnego - ani duchowego, ani cielesno-duchowego zjednoczenia kochanków. Romantyczna i modernistyczna androgynia zostaje zatem zakwestionowana, chociaż nie dzieje się to bezpodstawnie. Pisarz bowiem stara się określić przyczyny, które sprawiają, iż tego rodzaju koncepcja jest niemożliwa do realizacji.

\section{Wobec romantyzmu}

Prezentacja epifanii, której doznał Gustaw, widząc ukochaną, jest zbyt jednostronna, gdyż pozostaje ograniczona do perspektywy bohatera. Dlatego rozwijając Mickiewiczowski temat, Prus stara się pokazać, w jaki sposób następuje konstytucja owej boskości, którą kochanek obdarza swą wybrankę.

Proces ten, po pierwsze, nie jest momentalny, ale zakłada perspektywę temporalną. Po drugie jednak dokonuje się przy współudziale ko-

${ }^{15} \mathrm{G}$. Matuszek, Melancholik, mistyk, narcystyczny kochanek, samotny homo dolorosus, w: S. Przybyszewski, op. cit., s. 29. Por. W. Gutowski, Nagie dusze i maski. O młodopolskich mitach miłości, Kraków 1997, s. 242-264. 
chanki, która w tym celu posługuje się pewnymi strategiami. Przedstawiając zachowania Henryki i Karoliny, pisarz prezentuje dwa różne warianty kobiecej taktyki wraz $\mathrm{z}$ ich konsekwencjami.

Panna Henryka jest wyraźnie zadowolona ze starań swojego amanta, a nawet delikatnie go do nich zachęca. Jej kokieteria wydaje się niewinna, aczkolwiek jest podszyta próżnością, która czerpie zadowolenie ze skierowanego na jej osobę męskiego pragnienia. Anastazy zostaje więc przez Henrykę „wykorzystany” jako adorator, który zaspokaja jej miłość własną.

Mechanizm ten mógłby jeszcze długo funkcjonować, o ile pozostałby ukryty. Dzieje się jednak inaczej, gdyż Henryka (razem z bratem) pozwala sobie na niewybredny żart $\mathrm{z}$ absztyfikanta. $\mathrm{Z}$ tego powodu zrywa on dalszą relację, tłumacząc swe postępowanie następująco:

Więc to tak?... - myślałem drżąc $\mathrm{z}$ oburzenia. - Ja ją kocham, ja ją ubóstwiam, ja w mej duszy stawiam jej ołtarze, ja pragnę dla niej życie poświęcić, a ona drwi ze mnie?... (ZWC, 176) ${ }^{16}$.

Odkrycie jest zatem bolesne, ponieważ prowadzi bohatera do wnios$\mathrm{ku}$, iż on sam nie tylko nie był kochany, ale wręcz nie przedstawiał dla swej wybranki żadnej wartości. Uświadamiając sobie ten fakt, Anastazy dokonuje detronizacji, która sprowadza boginię do kategorii „piękności nieosobliwej”. Panna Karolina uzyskuje status „niebianki” w przeciwny sposób, gdyż początkowo okazuje bohaterowi zimną obojętność, a następnie unika z nim kontaktów, ograniczając je do niezbędnego minimum. Ta strategia okazuje się nadzwyczaj skuteczna, ponieważ Anastazy nie tylko się zakochuje, ale również popada w autentyczną zależność.

Doznawałem wobec niej - wyznaje - jakiegoś tkliwego poddania się, jakiejś wstydliwości, jakiejś wdzięczności dla tej mojej ukochanej, a jednocześnie pragnąłem dokonać niezwyklego aktu poświęcenia. Ale ponieważ w Warszawie trudno zostać bohaterem, więc obmyśliłem inny rodzaj szlachetnej ofiary (ZWC, 179).

Tego typu postawa stanie się odtąd dla bohatera znamienna. $\mathrm{Z}$ jednej strony jego pragnienie pozostaje na tyle zafascynowane niedostępną kobietą, iż wyrzeka się on wszelkiej samodzielności. Z drugiej jednak strony doznaje $\mathrm{z}$ tego powodu niejakiego upokorzenia, więc snuje kompensacyjne fantazmaty, w których sam okazuje się podziwianym przez ukochaną (i jej matkę) herosem.

Ten mechanizm również mógłby sprawnie funkcjonować, gdyby nie pojawili się „źli ludzie”. Jednakże Prus wprowadzając postać zwycięskie-

$16 \mathrm{~W}$ ten sposób odsylam do: B. Prus, Ze wspomnień cyklisty, w: Pisma, pod red. Z. Szweykowskiego, t. XXIV, Warszawa 1949; cyfra w nawiasie oznacza stronę. 
go konkurenta, inaczej niż Mickiewicz pokazuje trójstronne interakcje. Miłość między Karoliną a jej narzeczonym istniała uprzednio, dlatego nie jest niczyją kopią. Implicite obecna w Dziadach krytyka innych, którzy wykorzystując swą pozycję społeczną, imitują, a następnie niszczą prawdziwe uczucia, zostaje zatem anulowana.

Pisarz zarazem pokazuje, iż narodziny miłości bohatera przebiegają wedle zasady qui pro quo. Anastazy zakochuje się w Karolinie właśnie z powodu jej narzeczonego, chociaż nic o nim nie wie. Jej efektywna "strategia" nie jest bowiem działaniem celowym, ale wynika z zaznanego rozczarowania, a następnie $\mathrm{z}$ ponownego nawiązania dawnej relacji.

Podobne odwrócenie zostaje zastosowane w dalszym toku fabuły, która koncentruje się wokół cierpień zdradzonego kochanka. Mickiewiczowski Gustaw skupia doznania na sobie i kochance, jedynie nadmieniając o zazdrości o konkurenta. Prus natomiast pokazuje, iż to on jest najważniejszy, gdyż wzbudza najsilniejszą reakcję.

Anastazy planuje bowiem zemstę, w wyniku której zasadniczy atut męża Karoliny zostanie zniszczony, powodując jego decyzję samobójczą. Ten zamiar nigdy nie będzie zrealizowany, dlatego - podobnie jak w przypadku Gustawa - potencjał agresji zostaje przeniesiony z męża na odrzuconego amanta. Anastazy wprawdzie się nie zabija, ale niszczy podstawę psychicznego zdrowia. Popada w długotrwałą bezsenność, która czyni z niego „zjawę" istniejącą na granicy tego, co rzeczywiste i wyobrażone.

Częściowe uzdrowienie następuje w momencie, kiedy bohater wyrzeknie się odwetu, odwracając swą uwagę od rywala. Wówczas okazuje się, iż inne kobiety zaczynają się Anastazemu podobać, a Karolina nie wzbudza już w nim negatywnych reakcji. Fantazmatyczna wizja, w której dostrzega on „ślad” dawnej ukochanej w wielu kobietach, sugeruje, iż każda z nich może okazać się tą ,jedyną" i „niezastąpioną".

W tej sytuacji nieszczęśliwy kochanek może jedynie skupić się na sobie. Jak bowiem stwierdza bohater:

Człowiek niekiedy czuje dziką potrzebę rozdrapywać zabliźniające się rany i to okrucieństwo na samym sobie sprawia mu przyjemność. Więc $i$ ja czułem rozkosz oskarżając się o niepowodzenia miłosne (ZWC, 199).

Pełne uzdrowienie polega zatem na rezygnacji z autoagresji, która jest zastępczą formą rywalizacji. Prus pokazuje, iż proces ten jest niezwykle trudny, ponieważ mimo absurdalnych zarzutów, jakich wymaga, dostarcza realnej (a zarazem osiągalnej) satysfakcji związanej z ukaraniem „winnego". Na tym polega istota „obłędu na tle erotycznym”, przed którym Anastazy (zgodnie z radą lekarza) zamierza uciec, wyruszając na podwarszawskie drogi. 


\section{Wobec modernizmu}

O ile nawiązania do romantycznego arcydzieła pozostają w sferze aluzji17, o tyle kontekst modernistyczny Prus przywołuje bezpośrednio, i to zarówno w wymiarze ogólnym, jak i konkretnym związanym z utworem Przybyszewskiego ${ }^{18}$.

Anatazy sakralizuje ukochaną oraz silniej niż poprzednio podkreśla miłosną predestynację. Począwszy od pierwszej epifanii, pojawiają się określenia, które interpretują przypadkowe spotkanie w kategoriach metafizycznych:

Spojrzała... Jak ona spojrzała na mnie!... O, stójcie... Wszakże ona i ja jesteśmy więcej aniżeli rodzeństwem... jesteśmy połowami jakiejś mistycznej istoty... [...] Los mój zdecydowany... (ZWC, 245; por. ZWC, 255, 294, 305).

Przedstawiając finałowe perypetie Fitulskiego, pisarz szczególnie zwraca uwagę na deterministyczne założenia, które tkwią u podstaw tezy o "przedbytowym" związku dwojga kochanków.

Najważniejsza presupozycja dotyczy samego pragnienia. Jeśli bowiem oboje zostali złączeni na poziomie metafizycznym, to konieczne jest, iż stykając się ze sobą w przestrzeni fizycznej, natychmiast skierują ku sobie spontaniczne i niezmienne pragnienia. Prus analizuje tę kwestię z obu perspektyw i dochodzi do wniosku, iż tak silne warunki nie mogą być równocześnie spełnione. W przypadku kochanka pragnienie jest wprawdzie spontaniczne, ale nie jest niezmienne; natomiast w przypadku kochanki odwrotnie: pragnienie jest niezmienne, ale nie spontaniczne.

Anastazy zakochuje się bowiem najpierw w Hani, ale starając się do niej dotrzeć, trafia na Zosię, która także wzbudza w nim silny afekt. Ponownie zatem pojawia się qui pro quo, pokazujące, iż pragnienie nie jest jednoznacznie określone, dlatego swobodnie dokonuje „podstawienia” lub zamiany osób, którymi jest zainteresowane.

Anastazy spotyka Zosię, potem Hanię, a następnie znów Zosię. Za każdym razem natychmiast zakochuje się w jednej i zapomina o drugiej, by ostatecznie obie porzucić. Żadna $\mathrm{z}$ nich zatem nie wzbudziła $\mathrm{w}$ nim autentycznego uczucia; nie jest natomiast wykluczone, iż jego „zdwojone” zabiegi służyły zaspokojeniu miłości własnej.

17 Tylko niekiedy są one wyraźne. Np. starając się o pannę Karolinę, Fitulski stwierdza, iż: „Ja, skromny urzędnik bankowy, jeszcze nie mogłem myśleć o zapewnieniu sobie raju na ziemi [...]" - ZWC, 177; por. D IV, 1252.

18 Wyraźnym nawiązaniem jest motyw wiązanki kwiatów, które bohater Androgyne dostaje od nieznajomej wielbicielki. Prus rozdziela go między dwie bohaterki: Zosia wręcza Anastazemu kwiaty, a Hania - wstążkę. 
Początkowo obie panny zachowują wobec Anastazego konwencjonalny dystans, gdyż warszawski amant zdecydowanie nie zrobił na nich oszałamiającego wrażenia. Jednakże jego przemieszczenie $z$ domu rejenta do domu doktora i z powrotem dokonało zasadniczych zmian. Ironiczny stosunek Hani ulatnia się natychmiast, gdy tylko nabierze ona przekonania, iż Anastazy ukradkiem wzdycha do Zosi. I odwrotnie: Zosia przyjmuje wracającego od Hani bohatera $\mathrm{z}$ pełną atencją, okazując mu niedwuznaczne oznaki zainteresowania. Obie przyjaciółki są zatem zazdrosne o siebie i dlatego niepozorny Fitulski staje się dla nich tak atrakcyjny.

Zarówno w romantycznej, jak i modernistycznej androgynii Prus dostrzega dwa warianty, które można znaleźć już w platońskiej Uczcie. Pierwszy - zgodnie z koncepcją Arystofanesa - zakłada, iż całość, jaką tworzą kochankowie, ma w istocie charakter narcystycznego podwojenia, tautologicznej projekcji, jakiej dokonuje jedna ze stron. Drugi wariant zasugerowany przez Sokratesa - przyjmuje, iż połączenie dwojga kochanków dokonuje się ze względu na ich wartość, tak iż razem tworzą naturę zarówno jedną, jak i doskonałą.

Niezależnie jednak od tego, czy mit Androgyne będzie interpretowany w kategoriach jedynie „podwojenia” czy aż „dopełnienia”, zawsze zakłada bezpośrednią naturę relacji, która powstaje między podmiotami. Prus jest przekonany, iż taka sytuacja jest w zasadzie niemożliwa, a w każdym razie nie taka oczywista, jak przedstawiają ją niektóre utwory literackie. Tym bowiem, z czym nieustannie boryka się ludzka egzystencja, jest mediatyzacja, której ulegają międzyludzkie - a zwłaszcza miłosne - relacje.

Prus pokazuje ten mechanizm, wzmacniając lub osłabiając rolę partnera. W pierwszym, narcystycznym modelu okazuje się zatem, iż pozornie nieistotna funkcja tego, kto jest tylko „odbiciem”, staje się kluczowa. Samoafirmacja możliwa jest właśnie dlatego, że inny swoim zainteresowaniem już dokonał afirmacji. Miłość własna - a więc relacja podmiotu z sobą samym - jest niemożliwa do zaspokojenia bez kogoś, kto będzie cierpliwym adoratorem (wie o tym Henryka) lub będzie podziwial bohaterskie czyny, a przynajmniej warszawską elokwencję Anastazego.

W drugim modelu udział partnera jest natomiast minimalizowany. Najważniejszy okazuje się ten (ta), kto sugeruje taki właśnie wybór kochanka lub kochanki ${ }^{19}$. Prus unaocznia, jak nikła jest granica między

$19 \mathrm{Na}$ tę przypadłość charakteru Fitulskiego pierwszy zwrócił uwagę Szweykowski - por. Z. Szweykowski, Twórczość Bolesława Prusa, Warszawa 1972, s. 367. 
miłością a zazdrością czy raczej: jak często miłość jest nierozpoznaną formą zazdrości. Pomimo iż konkurent ujawnia się później (narzeczony Karoliny) lub jest tylko domniemany (Hania dla Zosi i odwrotnie), to jednak ma on (ona) decydujący wpływ na powstanie i przebieg „androgynicznego" uczucia. W obu zatem wariantach pojawia się zapośredniczenie, dlatego zamiast binarnej relacji kochanków Prus tworzy grę trójkątów, która wypełnia kompozycyjną klamrę. Ta reguła w końcowej patii znajduje wyraźne potwierdzenie $\mathrm{w}$ rozważaniach bohatera, który nie mogąc się pogodzić $\mathrm{z}$ istnieniem aż dwóch „aniołów”, stawia następujące pytanie:

Kto zresztą wie, czy w przedbytowej krainie owa doskonała istota, zwana przez poetów „androgyne”, składa się nie z dwu, lecz z kilku dusz ludzkich: jednej męskiej i dwu lub więcej kobiecych? (ZWC, 305).

To nie jest brukselkowy koncept ${ }^{20}$, a w każdym razie nie tylko. Prus pokazuje, iż androgyniczna metafizyka jest nieuchronnie skażona idealizmem. Pozostaje bowiem poza ludzką rzeczywistością, w której zamiast dwóch podmiotów uparcie pojawiają się trzy.

$\mathrm{Z}$ faktu, iż miłosne perypetie Anastazego umieszczone zostały w „strategicznych" miejscach, sądzić można, iż pozostała partia narracji została podporządkowana elementom okalającym. Intuicję taką potwierdza spostrzeżenie Michała Głowińskiego, który stwierdził, iż przestrzeń podwarszawskiej peregrynacji nie ma charakteru realistycznego, ale skonstruowana została wedle reguł alegorycznych ${ }^{21}$. Podróż i wyłaniający się z niej obraz prowincji posiadają więc sens naddany, który wykazuje bliski związek z tym, co zostało zawarte w ramie kompozycyjnej.

Wzajemne relacje między tymi odcinkami fabuły funkcjonują na co najmniej trzech płaszczyznach. Pierwsze dwie są dość oczywiste, ponieważ bezpośrednio powtarzają „dekonstrukcyjny” stosunek pisarza do romantycznej i modernistycznej androgynii. Natomiast poziom trzeci wskazuje na związki między pragnieniem a stanem kulturowego kryzysu, jaki zostaje zaaranżowany na podwarszawskiej prowincji. Wszystkie fantazmaty, które w trakcie podróży stwarza sobie Anastazy, są analogiczne do tych, jakie pojawiły się podczas nieudanych starań o rękę panny Karoliny. Ich funkcja sprowadza się bowiem do kompensacji, co trafnie dostrzegł Tynecki, pisząc, iż:

20 J. Tynecki, op. cit., s. 268.

${ }^{21}$ M. Głowiński, op. cit., s. 230-231. 
fantazjowania mają dwa aspekty - dotyczą roli (w wielu odmianach), którą sam bohater ma odegrać, i ról - które spełnić wobec niego mieliby inni. Ci inni w rojeniach zwłaszcza - to przeważnie tło; dawcy uznania, którego Fitulski potrzebuje ${ }^{22}$.

W obu zatem partiach narracji stawką w grze wyobraźni jest zaspokojenie miłości własnej, które stanie się możliwe dzięki udziałowi innych. O ile jednak początkowo Anastazemu wystarczyłby kameralny podziw dwóch kobiet, o tyle później konieczne byłyby hołdy całego narodu składane w trakcie oficjalnych uroczystości w Dolinie Szwajcarskiej. Ta zmiana pokazuje, jak bardzo zraniona została duma odrzuconego amanta. Dlatego nie jest on zdolny do spontanicznej wzajemności (nikomu nie odda nawet niepotrzebnych bułek), a jedynie do takiej, która jest wymagana przez normy społeczne (uiszcza opłaty za swoje zamówienia).

Kompensacyjne fantazmaty istotnie zakładają duży zestaw ról, jakie Anastazy zamierza odegrać. Wszelako można je zredukować do dwóch zasadniczych, z których pierwsza ma charakter prywatny, a druga publiczny. Bohater będzie albo pełnym poświęcenia kochankiem, albo reformatorem, który zgodnie z pozytywistycznym programem zainicjuje wiele działań na rzecz marginalnych warstw społeczeństwa. Jeśli zatem w obu przypadkach ukryty projekt jest taki sam, to Prus sugeruje, iż nie ma takiej sfery, która byłaby niepodatna na zawłaszczenie przez miłość własną. Przy takim mechanizmie różnica między romantycznym amantem a pozytywistycznym ideologiem okazuje się akcydentalna, gdyż dotyczy środków, a nie celu.

Jednakże podróż nie tylko dostarcza „pretekstów”, dzięki którym wyobraźnia Fitulskiego dokonuje egotycznych projekcji. Ciąg zdarzeń, w którym sukcesywnie uczestniczył bohater, zostaje bowiem przez niego odpowiednio wykorzystany, kiedy peregrynacja dobiegnie kresu. Odwiedzając zarówno Zosię, jak i Hanię, Anastazy barwnie opowiada o minionych wypadkach, które spowodowały jego obecność u każdej z panien. Pierwsza relacja kończy się w taki sposób:

Stosując się do rady genialnego lekarza - mówiłem dalej - chory pojechal dziesięć... dwadzieścia... trzydzieści wiorst za Warszawę... Nagle pęka mu rower... podróżny o mało nie traci życia... A gdy omdlały z bólu odpoczywa pod krzyżem... przeznaczenie zsyła mu zacnego starca, który nie tylko wyciągnął do niego dłoń pomocy, ale jeszcze zaprosił... przywiózł do swego domu, gdzie stęskniony, złamany życiem podróżnik spotyka osobę... (ZWC, 297).

Te same wydarzenia opowiadane dociekliwej Hani brzmią następująco:

- Powóz ruszyl i zostawił mnie w rozpaczy, którą ukoić może tylko śmierć... Na szczęście wdało się $\mathrm{w}$ to przeznaczenie, zbliżyło mnie z panem rejentem, którego nie znałem dotychczas i...

22 J. Tynecki, op. cit., s. 256. 
- Pan wierzy w przeznaczenie? - zapytała moja najdroższa, moja wyśniona.

- Jakże mam nie wierzyć?... Czyliż moje tęsknoty, moja choroba, przepis lekarza, spotkanie wczorajsze z panią w miasteczku, a wreszcie to, że dziś moglem opowiedzieć pani moją historię... (ZWC, 303).

W obu relacjach kluczowym terminem jest „przeznaczenie”. Sekwencja zdarzeń uzyskuje zatem spójne, celowościowe uporządkowanie, które prowadzi od wizyty u lekarza do odwiedzin u Zosi lub Hani. Oznacza to, iż następstwem wypadków rządzi ścisła, deterministyczna logika, która z żelazną koniecznością kieruje losami bohatera, eliminując wszystko, co nie prowadzi do ostatecznego celu. Przy takim założeniu dokonania bohatera stają się nieznaczące: niezależnie od tego, czy będzie on aktywny czy pasywny, jego przeznaczenie zawsze się spełni.

Taka koncepcja jest konsekwencją miłosnej predestynacji, którą silnie podkreślał modernizm. Jeśli kochankowie kiedyś stanowili jedność, to muszą ponownie się złączyć, zatem każdy fakt jedynie przybliża ten moment. Dlatego w Androgyne Przybyszewskiego narrator najpierw stara się odszukać zobaczoną przelotnie kobietę, a kiedy próby te nie przynoszą rezultatu, oddaje się snom i marzeniom na jawie. Suma tych „działan" i tak ostatecznie prowadzi do ponownego spotkania.

Prus jest niezwykle sceptyczny wobec takiego determinizmu. Porównanie narracji właściwej $\mathrm{z}$ opowieściami, jakie przedstawia obu pannom Anastazy, prowadzi do dwóch wniosków. Po pierwsze, bohater wprowadza do nich elementy, których pierwotnie albo nie było, albo nie posiadały przypisywanego im znaczenia. Historia opowiadana Zosi czyni z jej ojca osobę odpowiedzialną za przybycie Fitulskiego do Kulfonowa, podczas gdy faktyczną rolę odegrały manipulacyjne działania samego amanta. Natomiast historia opowiadana Hani „uzupełnia” bieg zdarzeń o lot gołębia, który rzekomo skierował bohatera w stronę miasteczka. Po drugie, obie historie skrzętnie eliminują niemałą liczbę zdarzeń, w których bohater wziął udział, a które w żaden sposób nie przybliżały jego spotkania z pannami. Są zatem fakty przypadkowe, a w każdym razie neutralne względem miłosnej predestynacji. Jej prezentacja natomiast niejednokrotnie opiera się na retorycznym zabiegu prefiguracji, który albo nie jest zupełnie prawdziwy, albo fałszywy.

Pisarz dyskredytuje obie historyjki, tak aby zasadnicza uwaga została skupiona na narracji właściwej. Z niej jednak wynika, iż ten sam ciąg zdarzeń prowadzi nie do jednego, lecz do dwóch zakończeń, z których każde okazuje się tym "ostatecznym". Istnienie takiej sytuacji jest sprzeczne z determinizmem, który nie dopuszcza dwóch finałów, gdyż wówczas ten pierwszy nie byłby niczym innym, jak tylko przedostatnim etapem. Prus pokazuje zatem, iż teorii miłosnej predestynacji nie sposób uzasadnić a priori w taki sposób, jak czyni to idealistyczna metafizyka. 
Empiryczne doświadczenia często przeczą tej koncepcji, a zatem dokonują jej falsyfikacji. Jedynym sposobem uprawomocnienia jest metoda, którą wobec obu panien zaprezentował Anastazy. Historię o miłosnym "przeznaczeniu” zawsze tworzy się ex post - a posteriori - używając w tym celu odpowiednich przemilczeń i strategii retorycznych.

Komponując obraz podwarszawskiej prowincji, Prus istotnie pokazuje nędzę oraz brak perspektyw, jakie wynikają z zaniedbań w zakresie realizacji programu pracy organicznej. Jednakże kwestią, która interesuje - a zarazem przeraża - pisarza najbardziej, jest zagadnienie międzyosobowych relacji, stanowiących ostateczną przyczynę katastrofalnego stanu, w jakim znajdują się te obszary. Ludzie mieszkający na nich pozostają bowiem $\mathrm{w}$ permanentnym konflikcie, który niejednokrotnie prowadzi do użycia przemocy.

W 1890 roku entuzjastycznie recenzując jedną ze sztuk o tematyce wiejskiej, Prus podkreślał, iż jej bohaterowie pełni są rozmaitych namiętności:

Nikt tam nie goni za abstrakcją, ale za ziemią, pieniędzmi albo kobietą. Nikt nie ulega prądowi chorego uczucia, ale tej elementarnej sile, która nie cofa się ani przed kulą, ani przed nożem, ani przed poświęceniem. Trzeba, to trzeba i tyle ${ }^{23}$.

Obraz prowincji zostal skomponowany wedle tej triady, $\mathrm{z}$ tą jednak różnicą, iż za każdym razem pisarz wskazuje na mediacyjną naturę owej siły, jaka kieruje ludzkimi zachowaniami.

Mechanizm ten jest przez pisarza najbardziej eksponowany w tych sytuacjach, w których obiektem zainteresowania jest kobieta. W tej dziedzinie najlepiej widoczna jest spójność całej narracji, w której to, co doświadczane oraz obserwowane przez Anastazego, wykazuje analogie. Romantyczni kochankowie ${ }^{24}$ (Lubomir i Eloida) - podobnie jak napotkani na przedmieściach adoratorzy Heleny - są zaangażowani w rywalizację. Przetrwała ona nawet zgon jednego z nich, o czym doskonale wie Elodia:

- Mąż mój - rzekła spuszczając oczy - jest ojczymem Felisia i ... jest do niego uprzedzony... Chłopak przypomina mego pierwszego nieboszczyka, a Lubomir umie być zazdrosnym nawet o zmarłych... (ZWC, 242).

Parafrazując znaną sentencję, można stwierdzić, iż to zazdrość jest potężna jak śmierć, zarówno dlatego, iż wiąże konkurentów nierozerwalnym węzłem, jak i z powodu skutków, do jakich prowadzi.

${ }^{23}$ B. Prus, Kroniki, oprac. Z. Szweykowski, t. XII, Warszawa 1962, s. 259.

${ }^{24}$ Taką proweniencję imion tych bohaterów ustalił T. Budrewicz - T. Budrewicz, op. cit., s. 245. 
Na prowincji nie pojawia się walka o samą ziemię, ale - o jej płody. Napadnięty chłop zaciekle broni swoich ziemniaków przed tymi, którzy w sposób równie bezwzględny je rabują. Zresztą nawet zmiana strategii, polegająca na uporczywej prośbie, nie zawsze zapobiega przemocy: żebrak Bartek w karczmie czasami dostaje pożywienie, ale niekiedy jego starania kończą się gwałtownym wybuchem agresji u tych, do których się zwraca.

Pieniądze wzbudzają najsilniejsze namiętności, które nie prowadzą do otwartego użycia siły, chociaż wywołują stan zagrożenia. Oszukany nie tylko finansowo - przez Rzempolskich Dzięgiel zostaje opanowany przez nienawiść, która nieuchronnie pcha go do zemsty. W rozmowie $\mathrm{z}$ rejentem doskonale wyraża on swe zamiary wobec (błędnie zidentyfikowanego) panicza:

- Niech go pan rejent uprzątnie stąd, Rzempolszczaka, bo jak mi co do głowy uderzy, złapię siekiery i zgładzę piekielne nasienie... (ZWC, 273).

Wierzgajło rozumie wagę tych słów, gdyż sam, przewożąc znaczną kwotę, obawia się napadu Olejarka. Niezależnie zatem od tego, czy rabunek już nastąpił czy też jest dopiero spodziewany, prowadzi do analogicznych procesów. I rejent, i chłop broń trzymają stale $\mathrm{w}$ pogotowiu, a ich uwaga nieustannie jest skoncentrowana na osobie - faktycznego czy domniemanego - napastnika. Prowadzi to do prawdziwej fiksacji, która upatruje we wszystkich ludziach wroga, z którym natychmiast trzeba będzie się zmierzyć.

Pomimo iż w tym ostatnim przypadku żadne działania nie zostają podjęte, to jednak gdyby doszło do konfrontacji, prawdopodobnie zakończyłaby się ona zabójstwem. Wszelako nie wynika to $\mathrm{z}$ faktu, iż pieniądze - w przeciwieństwie do pozostałych „przedmiotów” - są w stanie wygenerować silniejszą rywalizację. Prus wyraźnie podkreśla symboliczną naturę pieniądza, która nadaje jego właścicielom odpowiednią pozycję25. Rejent pozbawiony kapitału (na posag córki) zostałby zdeklasowany, czego już doświadczył - wobec Niemców i Żydów - Dzięgiel. Kradzież dokonuje zatem zaburzeń w społecznej hierarchii, a nawet - w przypadku otwartego konfliktu - mogłaby doprowadzić do jej zniesienia.

Ta kwestia zostaje jedynie zasygnalizowana, ale w sposób znaczący, ponieważ wskazuje na międzyludzkie konflikty, które są odpowiedzialne za destabilizację porządku społecznego. Komponując obraz prowincji, Prus nieustannie wprowadza ten temat, który przybiera postać zaniku czytelnych dystynkcji między odmiennymi sferami. Anastazy obserwuje $\mathrm{z}$ bliska ten proces, a nawet podaje jego definicję, stwierdzając, iż jest to:

${ }^{25}$ Pisarz także w dyskursie publicystycznym kładł nacisk na „sławę, szacunek, władzę nad ludźmi”, które zdobywa się stanem (często nieuczciwie) posiadanego kapitału por. B. Prus, op. cit., s. 301-302. 
„Dziwna plątanina wypadków i charakterów!...” (ZWC, 245). Każdy, albo prawie każdy, znajduje się w sytuacji, która nie odpowiada jego pochodzeniu. Potomkowie szlacheckiego rodu prowadzą karczmę, a chłopska rodzina Dzięgielów zachowuje się niczym rodowa arystokracja. Napotkany chłop, który pracuje w Prusach, posiada wyobraźnię godną mieszczańskiego inteligenta; i nawet obdarte dzieci bawią się w dorosłe wojsko.

Chaos nie tylko niweluje zewnętrzne przedziały, ale pojawia się także wewnątrz odmiennych grup. Chłopi na jarmarku - czy w zarażonej tyfusem chacie - zachowują się identycznie; podobnie jak wielmożni państwo Zaspalsy, o których nie można nic indywidualnego stwierdzić poza tym, iż grają w karty w określonym miejscu. Dążenie do niwelacji zasadniczych różnic jest najbardziej sztucznym zabiegiem, który nadaje tej narracji alegoryczny wymiar. Wydaje się bowiem, iż tzw. rzeczywistość nie wyglądała aż tak chaotycznie, jednakże Prus wyciągnął konsekwencje, które wynikają z nasilających się konfliktów.

Ostatnim etapem tego „eksperymentu" jest wprowadzenie kolektywnej przemocy wobec wybranych jednostek. Przykład Felka pokazuje, iż w sytuacji zaniku porządku przemoc niezwykle łatwo się rozprzestrzenia, szukając w tym celu obiektów zastępczych. Kulminacja tego procesu polega na wspólnym prześladowaniu, które w sposób czynny pokazane zostało na przykładzie torturowanego jastrzębia, a biernie było stosowane wobec studniarza, któremu nikt z otaczających go ludzi nie pomógł wydostać się z błotnistej studni. Chociaż obie sytuacje kończą się śmiercią, to jednak nie przez wszystkich jej zadawanie jest akceptowane: brak jednomyślności $w$ tych działaniach jest jedynym symptomem nadziei, jaka pojawia się w tych ponurych epizodach. Nadziei, istotnie związanej z tymi, którzy - jak oświecony chlop czy lekarz Biedroński - związali projekt egzystencji z programem pracy organicznej.

\section{VI}

Ze wspomnień cyklisty jest niewątpliwie utworem parodystycznym, który kompromituje nie tylko wzorce literatury młodopolskiej26, ale i romantycznej. Jednakże nie jest tak, iż Prus koncentruje się wyłącznie na polemice, nicując określone poetyki oraz stojące $u$ ich podstaw mitologie. Pisarz bowiem przeciwstawia im własną wizję, która nieodzownie po-

26 Por. M. Głowiński, op. cit., s. 231-232. Poza Szweykowskim (por. Z. Szweykowski, op. cit., s. 369-370) przekonanie takie (trafne, ale niepełne) sformułował Tadeusz Różewicz na kartach Dziennika gliwickiego, pisząc: „Czytam Sienkiewicza Bez dogma. tu - chyba Prusa Ze wspomnień cyklisty jest świadomq parodiq. Leon Płoszowski jest serio, głupszy i śmieszniejszy. Prus był jednak mądrzejszy od Sienkiewicza" - T. Różewicz, Matka odchodzi, Wrocław 2000, s. 85-86. 
wraca do problemów zapośredniczonego pragnienia i rodzącej się z niego przemocy. $\mathrm{Z}$ tego powodu to opowiadanie spełnia oba warunki tzw. parodii konstruktywnej, która - wedle definicji Głowińskiego:

Jest, jak wszelkie wypowiedzi tego rodzaju, dialogiem $\mathrm{z}$ innymi tekstami, ale stanowi także regułę budowania własnego świata, staje się jednym z czynników umożliwiających ekspresję własnej problematyki, tej, która w parodiowanych wzorcach nie tylko się nie pojawiła, ale nawet pojawić się nie mogła, polega przeto na budowaniu przez zaprzeczenie ${ }^{27}$.

Prus wprawdzie nie stworzył tu wnikliwej analizy mechanizmów mediacyjnych, ale uczynił to $\mathrm{w}$ innych powieściach, do których odsyłał czytelników chcących zapoznać się z jego refleksjami. Bezpośredni bowiem cel, który pisarz brał pod uwagę, angażując się w polemikę, polegal na ostrzeżeniu skierowanym pod adresem młodego pokolenia. Prus przestrzegał przede wszystkim przed uleganiem literackiej modzie, która jest zjawiskiem par excellence mimetycznym, z czego twórcy ci nie zdawali sobie sprawy. Tematyka rozstrojonej podmiotowości była nie tylko powielana, ale i traktowana bezrefleksyjnie. Dlatego nikt nie zorientował się, że stanowi ona zaledwie powtórkę - tyle że wyrażoną w innym języ$\mathrm{ku}-\mathrm{z}$ tego, co zostało zawarte w literaturze romantycznej.

Pod względem metaliterackim Ze wspomnień cyklisty stanowi beletrystyczną ilustrację listu, który ponad dziesięć lat wcześniej Prus napisał do Oktawii Żeromskiej. Wyrażał w nim swoją opinię o pierwszych utworach jej męża, którego uważał za najlepszego przedstawiciela nowego pokolenia. Prozatorski debiut Żeromskiego Prus przyjął życzliwie, aczkolwiek nie bez zastrzeżeń.

W każdym obrazku - pisal - są rzeczy piękne i wzruszające; brak tylko (co jest naturalne i konieczne) opanowania przedmiotu, a nade wszystko - tematu, własnych myśli. Niech czyta arcydzieła literatury powszechnej (Homer, Sofokles, Dante, Szekspir, Milion, Molier itd., itd.), a oszczędzi sobie mnóstwo czasu na wynajdywanie właściwych dróg ${ }^{28}$.

Wnikliwa obserwacja mechanizmów psychologiczno-socjologicznych (zwłaszcza na początku) nie jest łatwa, dlatego pisarz radzi korzystać z dorobku klasyków. Nie ma wśród nich romantyków, gdyż dialog z nimi - tak jak w przypadku Prusa - zawsze jest polemiką, na jaką nie zawsze stać początkujących. Lepiej byłoby zatem, gdyby uczyli się od tych, którzy wiedzą więcej na temat międzyludzkich interakcji, zamiast niewolniczo kopiować indywidualistyczne dogmaty.

27 M. Głowiński, Parodia konstruktywna (O „Pornografii" Gombrowicza), w: tegoż, Gry powieściowe. Szkice z teorii $i$ historii form narracyjnych, Warszawa 1973, s. 282.

${ }^{28}$ B. Prus, Listy, oprac. K. Tokarzówna, Warszawa 1959, s. 195. 